\title{
34. STRATIGRAPHIC SIGNIFICANCE OF VOLCANIC ASH IN PALEOCENE AND EOCENE SEDIMENTS AT SITES 549 AND $550^{1}$
}

\author{
Robert W. O'B. Knox, Institute of Geological Sciences, Leeds ${ }^{2}$
}

\begin{abstract}
Two ash horizons have been identified in Hole 549, one in the upper Paleocene (basal NP9), the other in the upper Eocene (NP18); both are mixed lithic crystal tuffs of rhyolitic composition. These tuffs are absent in Hole 550 owing to unconformities, but the basal Eocene (NP10) of Hole 550 includes a series of over 50 thin bentonite layers. Intermediate plagioclase associated with these bentonites indicates that the original ash was of basaltic to andesitic composition. The bentonites are absent in Hole 549, probably because of an unconformity, but they have been identified in Hole 401 (Leg 48, Bay of Biscay). Two of the pyroclastic phases can be matched with phases previously reported for the North Sea Ba$\sin$. The bentonites of Site 550 are probably equivalent to the widespread "ash series" of northwestern Europe, which may therefore be regarded as being lower Eocene in terms of Martini's calcareous nannoplankton zonation.
\end{abstract}

\section{INTRODUCTION}

Shipboard examination of smear slides from Paleogene sediments of Sites 549 and 550 (Fig. 1) revealed the presence of two horizons rich in volcanic ash, as well as more widespread disseminated material of volcanic origin. In this study, the nature and distribution of the volcanic material are examined in more detail, and its significance is assessed in terms of regional northeastern Atlantic volcanism.

The results reported here are based on a re-examination of the cores and on analyses of 48 samples from Hole 549 and 46 samples from Hole 550. The two previously identified ash-rich horizons were located in the cores, and a careful search was carried out for signs of other primary ash concentrations. This resulted in the discovery in Hole 550 of over 50 bentonite layers, which had escaped identification in smear slides because of the nearly total destruction of the primary volcanic textures. Despite the extensive argillization of the original glass, the bentonites retain enough primary constituents to allow a rough assessment of their original compositions. Their presence is of considerable significance in a regional context, as discussed herein.

\section{PETROLOGY}

\section{Hole 549}

Two ash-rich horizons are present in the cores of Hole 549, as recognized by the shipboard scientists. The Paleocene (NP9) ash in Sample 549-18-2, $66 \mathrm{~cm}$, is dark gray, friable, and of fine sand grade. At the time of study the ash layer in the core was considerably disturbed; nevertheless, it appears to have been at least 1 $\mathrm{cm}$ thick, with sharp contacts, and with internal vertical grading. The ash consists largely of grayish brown,

\footnotetext{
${ }^{I}$ Graciansky, P. C. de, Poag, C. W., et al., Init. Repts. DSDP, 80: Washington (U.S. Govt, Printing Office).

Institute of Geological Sciences, British Geological Survey, Leeds LS15 8TQ, United Kingdom (present address: British Geological Survey, Keyworth, Nottingham NG12 5GG, United Kingdom).
}

slightly turbid glass. The fragments range from equant to elongate, the Iatter displaying stretched vesicles and ribbed outer surfaces (Plate 1, Figs. 1-3). Mineral inclusions are absent, but the glass is accompanied by fresh, angular, fragmented feldspar crystals showing sharply defined cleavage surfaces or conchoidal fracture surfaces. The upper Eocene (NP18) ash in Sample 549-2-3, $129-131 \mathrm{~cm}$, is colorless, of fine sand grade, and occurs disseminated through nannofossil ooze. The morphology of the glass and feldspar crystals is similar to that in the Paleocene ash, except that the glass is commonly packed with minute vesicles (Plate 1, Figs. 5-7).

Electron microprobe analyses of glass from both ashes are given in Table 1. The ashes appear to have approached a rhyolitic composition, judging by the high silica contents. The feldspars, also determined by microprobe, are sanidines in the upper Eocene ash; those of the Paleocene ash are more sodic, straddling the sanidine/anorthoclase boundary (Fig. 2).

Disseminated ash particles occur sporadically at other levels in the core, particularly in Samples 549-15-5, $86-88 \mathrm{~cm}$, and $529-16-1,65-67 \mathrm{~cm}$. In these samples the ash is of a brown globular variety, similar to that associated with the bentonites of Hole 550 (see discussion of Site 550). The presence of relatively common brown amphibole crystals in Sample 549-17-2, 122-124 cm, and of scattered aegirine and brown amphibole crystals in Sample 549-16-6, 129-131 cm, indicate that minor falls of crystal ash took place in late Paleocene times, probably in association with the acidic volcanism that produced the underlying rhyolitic tuff.

\section{Site $\mathbf{5 5 0}$}

Disseminated brown to olive palagonitized globular ash particles are common in many samples from Cores 27 to 32 inclusive. This ash is similar to that encountered in Hole 549 (Cores 15 and 16) in sediments of comparable age. In Hole 550, however, the basal cores also include a number of thin, discrete bentonite layers. These are gray when fresh, probably owing to small amounts of pyrite, but on oxidized surfaces they are al- 


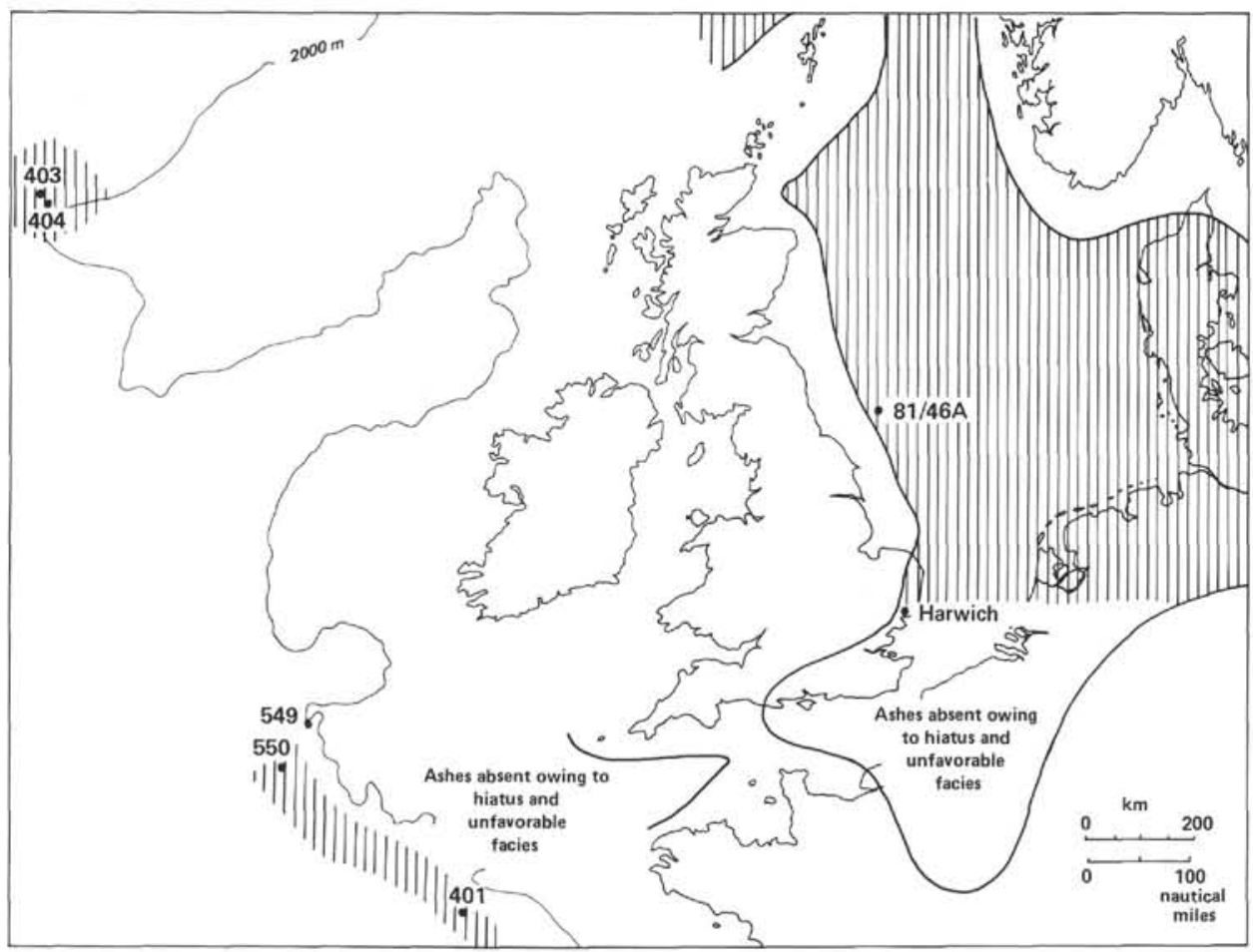

Figure 1. Location map. Hatched area shows known distribution of lower Eocene tuffs and bentonites.

Table 1. Electron microprobe analyses $(\%)$ of typical samples of upper Paleocene and upper Eocene glass particles.

\begin{tabular}{lcc}
\hline Oxide & $\begin{array}{c}\text { upper Paleocene } \\
\text { Sample 549-18-2, } \\
66 \mathrm{~cm}\end{array}$ & $\begin{array}{c}\text { upper Eocene } \\
\text { Sample 549-2-3, } \\
129-131 \mathrm{~cm}\end{array}$ \\
\hline $\mathrm{SiO}_{2}$ & 78.3 & 74.6 \\
$\mathrm{Al}_{2} \mathrm{O}_{3}$ & 12.0 & 14.3 \\
$\mathrm{FeO}$ & 1.2 & 4.4 \\
$\mathrm{TiO}$ & 0.2 & 0.8 \\
$\mathrm{MnO}$ & 0.2 & 0.3 \\
$\mathrm{MgO}$ & 0.0 & 0.4 \\
$\mathrm{CaO}$ & 0.6 & 0.4 \\
$\mathrm{Na} 2 \mathrm{O}$ & 2.0 & 0.9 \\
$\mathrm{~K}_{2} \mathrm{O}$ & 5.5 & 3.9 \\
\hline
\end{tabular}

tered to olive brown. Despite extensive argillization, the bentonites retain a granular texture in hand specimen, from which it can be seen that the ashes consisted of very fine sand- to silt-sized particles showing well-defined vertical grading. Many of the bentonites have, however, suffered substantial bioturbation, resulting in mixing with sediments above and below. Fifty-six distinct bentonite layers have been identified (Fig. 3), ranging up to 2 to $3 \mathrm{~cm}$ in thickness. Traces of another nine layers have also been noted, and it is possible that additional thin ash layers were originally deposited but subsequently obliterated by bioturbation.

The bentonites consist essentially of montmorillonite, but removal of the clay fraction leaves a residue of very fine sand- to silt-grade particles. These consist of brown to olive globular palagonitized glass particles (Plate 1, Figs. 8 and 9), some of which contain feldspar microlites, and angular euhedral or fractured plagio- clase crystals. This assemblage appears to be identical to that of the disseminated ash, although in the latter it is rarely possible to distinguish the volcanic feldspars from those of detrital origin. The bentonites also contain rare euhedral apatite crystals and, more commonly, aggregates of radial fibrous zeolite, probably phillipsite. An isolated extremely thin ash layer (Sample 550-29-1, 76 $\mathrm{cm}$ ) contains feldspathic glass particles, phillipsite aggregates, and scattered aegirine crystals. Rare aegirine crystals are also present in Sample 550-29-4, 138-140 $\mathrm{cm}$.

Removal of some layers during shipboard sampling, together with extensive bioturbation, has meant that relatively few uncontaminated bentonite samples were available for detailed mineral and chemical analysis. Nevertheless, feldspars from four bentonites have been analyzed. The associated residual palagonitized glass particles have not been analyzed, because their obvious alteration is presumed to have modified their original composition. The feldspars mostly range between andesine and calcic labradorite $\left(\mathrm{An}_{36}-\mathrm{An}_{66}\right)$ (Fig. 2); sporadic grains of other compositions probably represent a combination of contamination at the source and detrital contamination. The original magmas would appear to have been of basaltic to andesitic composition.

\section{STRATIGRAPHIC SIGNIFICANCE}

\section{Correlation between Sites}

A remarkable feature of the volcanic ash deposits at Sites 549 and 550 is that none of the discrete layers has been identified at both sites. For the Paleocene and upper Eocene tuffs, the explanation is simple-paleontological evidence clearly indicates unconformities in the 


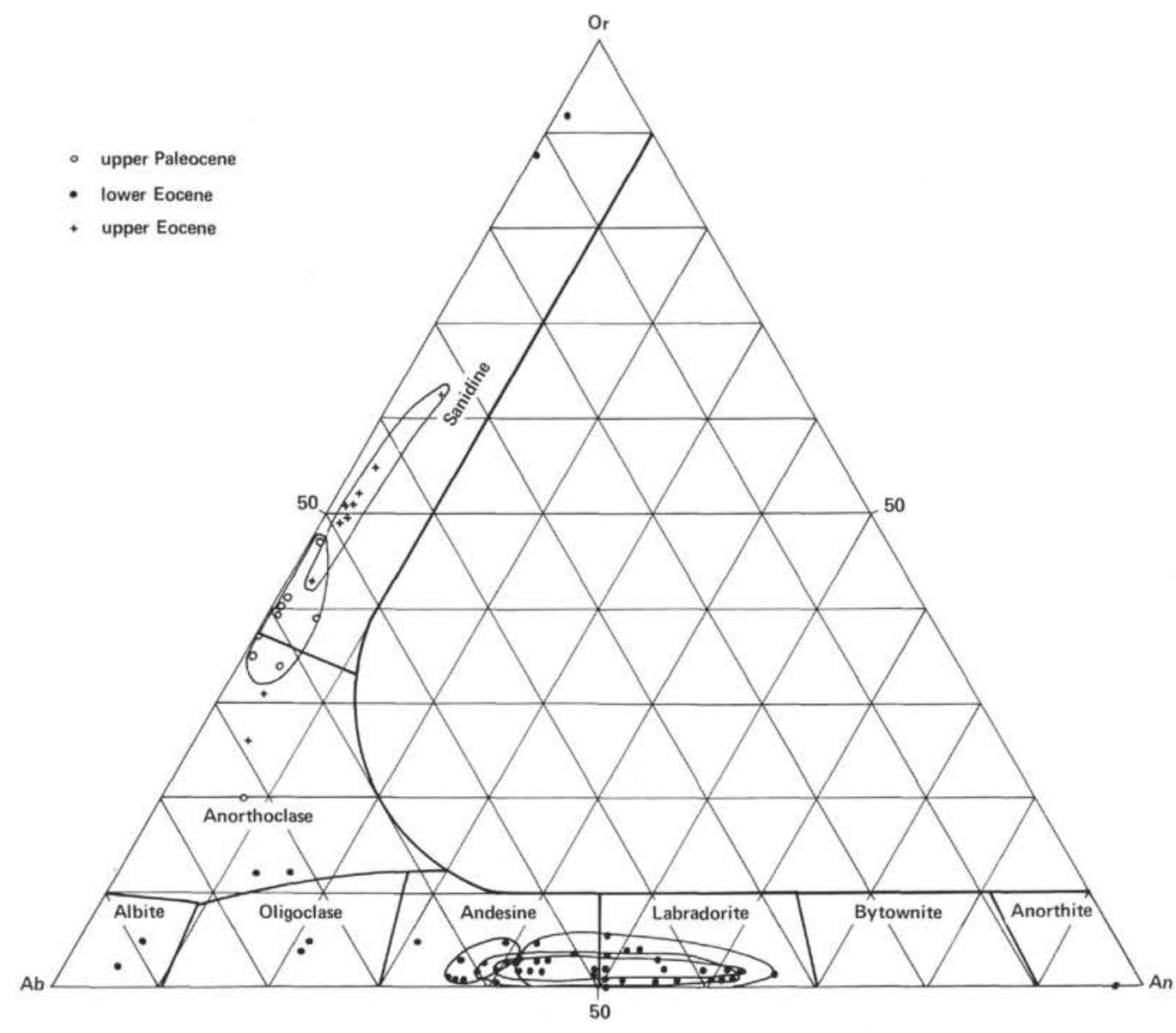

Figure 2. Feldspar phenocryst compositions in upper Paleocene, lower Eocene, and upper Eocene tuffs and bentonites. Enclosures represent principal compositional ranges of individual ash layers. Composition from microprobe analysis data.

relevant intervals in Hole 550. For the lower Eocene (NP10) bentonites of Hole 550, however, the evidence of an unconformity is less clear-cut. Zone NP10 is represented in Hole 549 , but the sediments are very much thinner (4 m) than those of Hole 550 (42.5 m) (Fig. 4). Because of the absence of the bentonites in Hole 549, the most plausible explanation of the contrast in thickness would seem to be that the lower part of Zone NP10 as developed in Hole 550 is absent in Hole 549, and that the NP10 sediments of Site 549 are equivalent to only the upper NP10 sediments of Site 550. The probable correlation between the two sites, as inferred from this discussion, is shown in Figure 4.

This interpretation is supported by paleontological data. In Hole 550, a continuous NP9/NP10 sequence is indicated by the presence of Rhomboaster cuspis in both uppermost NP9 and lowermost NP10 sediments (see Müller, this volume). In Hole 549, however, the NP10 sediments lack $R$. cuspis (see Müller, this volume), but even the basal sample includes Marthasterites contortus - a form normally associated with the upper part of Zone NP10. This indicates that the lower part of Zone NP10 is missing. A hiatus at the NP9/NP10 boundary in Hole 549 is further indicated by a sharp lithologic change across the boundary and perhaps also by the simultaneous FAD of three planktonic foramini- fers, Morozovella wilcoxensis, $M$. subbotinae, and $M$. marginodentata (see Site 549 chapter, this volume).

\section{Regional Correlation}

The presence of a substantial sequence of bentonites in the basal Eocene sediments of the Goban Spur area naturally leads to speculation that the same bentonites might be identifiable in adjacent areas of the northeastern Atlantic and perhaps even farther afield. For this reason, cores from Holes 400A and 401, Leg 48, Bay of Biscay (Fig. 1), were examined. Unfortunately, there was substantial core loss over the relevant interval in Hole $400 \mathrm{~A}$, but the NP10 sediments of Hole 401 contained several bentonite layers (Fig. 2). The bentonite layers and traces are fewer than in Hole 550 (14 compared with 56), and show signs of reworking and synsedimentary oxidation. However, further ashes may exist in the underlying interval of core loss. No bentonites have been observed in Hole 401 that would correlate with the sporadic bentonites in the lower Zone NP10 of Hole 550 . This is not surprising in view of the more condensed nature of the sequence, and there seems little doubt that the bentonites of Hole 401, though less well preserved, are equivalent to those of Hole 550.

There are no other reported occurrences of basal Eocene bentonites or ashes in the general area of the Go- 


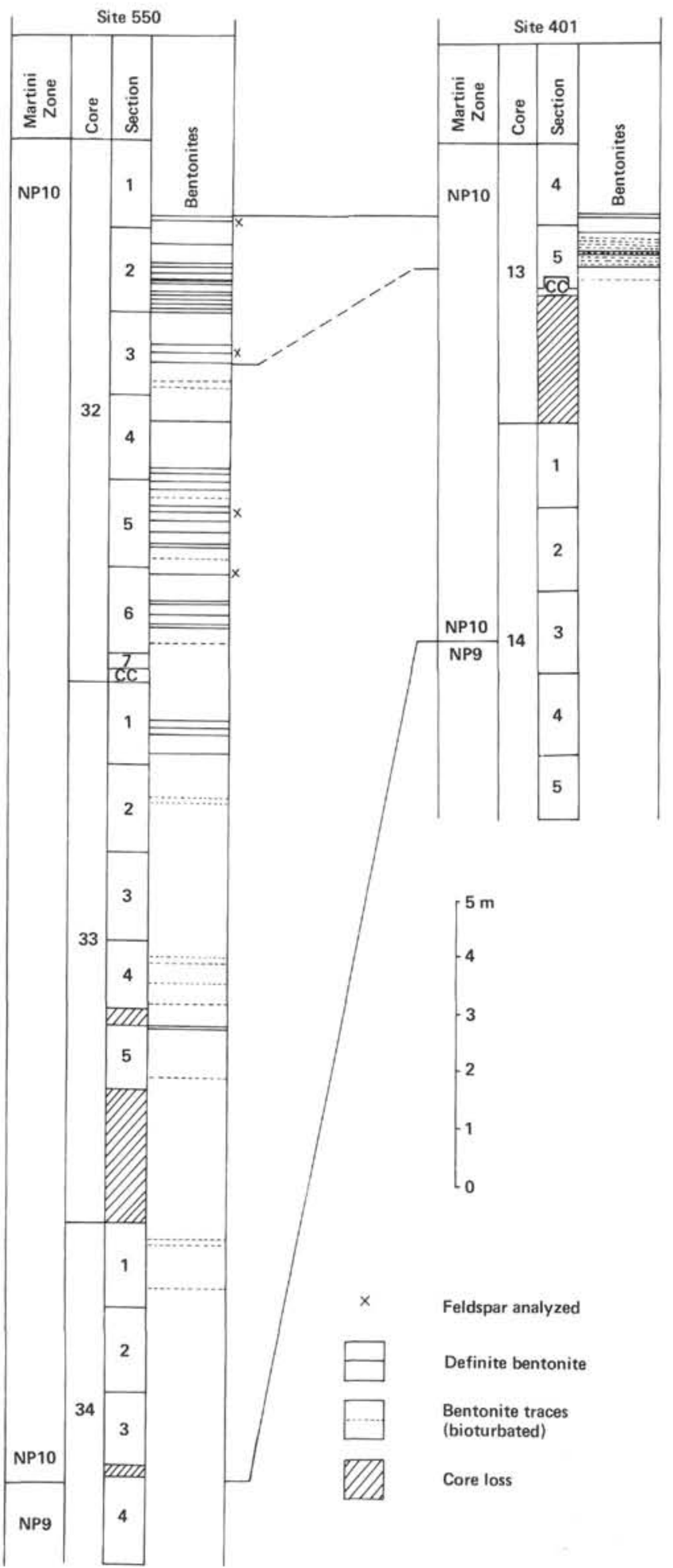

Figure 3. Distribution of bentonite layers in lower Eocene sediments of Holes 550 (Goban Spur) and 401 (Bay of Biscay).

ban Spur, there being a hiatus at that level in adjacent shelf sequences. The existence of a series of ashes in countries bordering the North Sea has, however, been known for many years (B $\phi$ ggild, 1918; Andersen, 1937), and these ashes have since been shown to occur throughout the North Sea area itself (Jacqué and Thouvenin,
Site 549

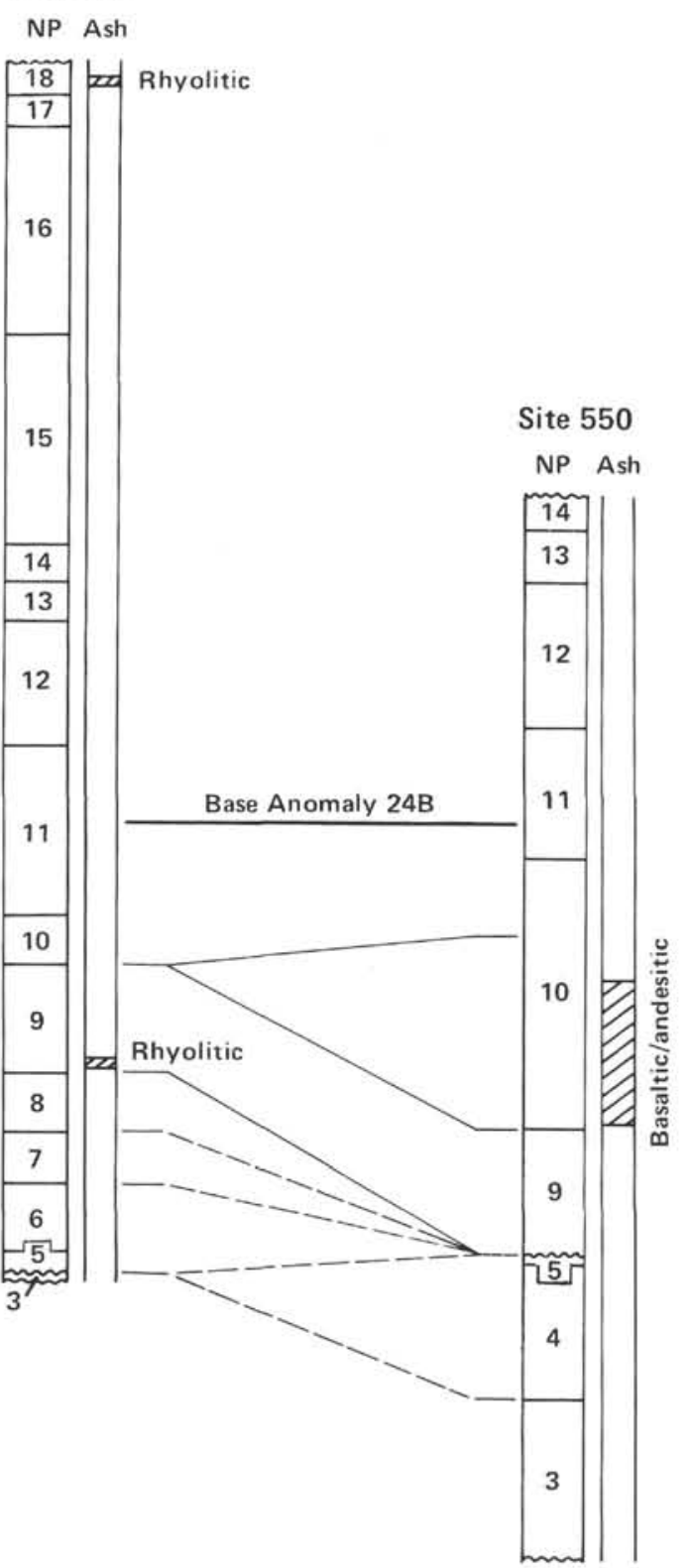

Figure 4. Correlation between Holes 549 and 550, explaining the lack of ash layers common to both sections.

1975; Knox and Morton, 1983). Over 150 ash layers have been recorded, and in the northern North Sea and Denmark some of the ashes reach a thickness of 15 to $20 \mathrm{~cm}$. In southwestern parts of the basin, however (e.g., Institute of Geological Sciences Borehole 81/46A, Figure 1), the maximum number of ashes is reduced to about 70 and the maximum thickness reduced to $10 \mathrm{~cm}$. In view of this trend and in the absence of stratigraphically adjacent ashes, it seems highly likely that the Goban Spur bentonites are distal equivalents of the North Sea Basin ashes. It should be noted, however, that the distribution trends may be more complicated in detail because of possible contributions by more than one volcanic center. Nevertheless, preliminary analyses of the $81 / 46 \mathrm{~A}$ volcanic plagioclases indicate a broad composi- 
tional similarity with those of Hole 550 and also with those of the Danish ashes (Pedersen et al., 1975).

Ashes of a very similar composition are also present in the Rockall area. These have been encountered on Legs 48 and 81; they are zoned NP10 and are considered equivalent to the North Sea ashes (Morton and Keene, in press). The Goban Spur ashes would thus appear to be the distal representatives of a major phase of explosive volcanism that affected the entire northeastern Atlantic region (Fig. 1). The source of the ashes lay to the north of the Goban Spur area, and their eruption is thought to have taken place in the tensional phase which preceded the separation of Greenland from Rockall (Knox and Morton, 1983).

Equating the North Sea Basin "ash series" with the bentonite sequence in the Goban Spur area would provide the first opportunity for relatively accurate indirect correlation of Martini's calcareous nannoplankton zones with the barren northwest European Paleocene/Eocene boundary beds. The Goban Spur bentonites and those of the Biscay area fall entirely within Zone NP10, with the basal layers laying close to the base of the zone. Because it is likely that the onset of ash eruption was more or less synchronous throughout the region, it would seem possible to locate the approximate position of the base of Zone NP10 in the North Sea Basin by the up-section influx of ashes. This would place the classic "ash series" sequences of Denmark and North Germany, together with the Balder and Sele formations of the North Sea area, within Zone NP10 and hence, according to Martini's scheme, within the lower Eocene (Fig. 5). Because of facies change and unconformities, the ashes are absent over much of southern England, in the Paris Basin,

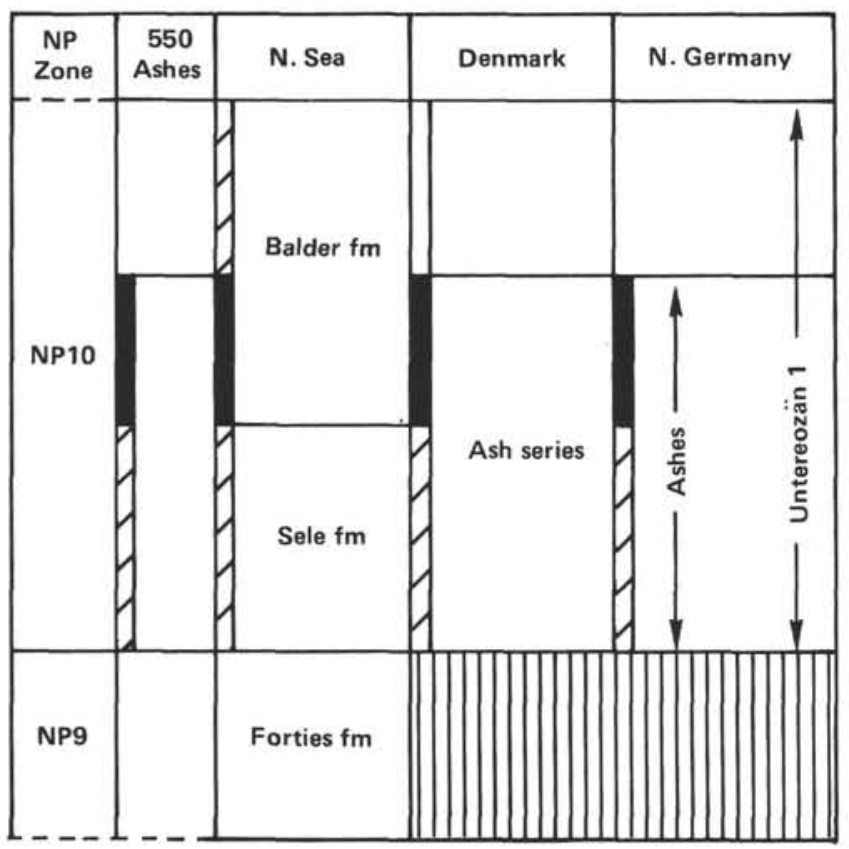

Figure 5. Correlation of lower Eocene ash-bearing sequences in the Goban Spur and Biscay areas with those in the North Sea Basin. Narrow hatching, wide hatching, and solid black represent sparse, moderately abundant, and very abundant ash layers, respectively. in the offshore areas of the English Channel, and in the Western Approaches Basin (Fig. 1). Equivalents of the lower part of the ash-bearing sequence would, however, appear to be present in the Woolwich and Reading beds of southern England.

Of the two other ash-bearing intervals, that of the upper Paleocene (NP8-NP9) is also recognizable in the North Sea area (Knox and Morton, 1983: Phase I). The upper Eocene (NP18) phase is not known in the North Sea area, but this may simply result from scarcity of cores over the relevant interval.

\section{CONCLUSIONS}

The lower Paleogene tuffs and bentonites of the Goban Spur Sites 549 and 550 correlate well with pyroclastic deposits recorded elsewhere in the northeastern Atlantic region. The lower Eocene bentonites in particular appear to be the southwestern, distal representatives of a major pyroclastic province. The close correspondence between the base of the bentonite sequence and the base of Zone NP10 suggests that the up-section influx of ashes could provide a useful marker for the base of Zone NP10 in adjacent northwest European sequences which are barren of calcareous microfossils.

Preliminary analyses of selected Goban Spur bentonites and North Sea ashes suggest that the feldspar phenocryst population of individual layers may be sufficiently distinctive to allow long-distance correlation. I intend to pursue this line of investigation as suitable material becomes available, but for the time being the correlation between the Goban Spur and North Sea ashes should be regarded as a probability rather than a certainty.

\section{ACKNOWLEDGMENTS}

I would like to thank Dr. C. Müller and Dr. S. Snyder for providing information on nannoplankton and foraminifer zonations, respectively, and C. King and Dr. O. B. Nielsen, who acted as referees and provided useful comments on the original typescript. The paper is published with the approval of the Acting Director, Institute of Geological Sciences (N.E.R.C.).

\section{REFERENCES}

Andersen, S. A., 1937. Den vulkanske Askelag i Vejgennemskaeringen ved Ølst og deres Udbredelse i Danmark. Danm. Geol. Unders., Raekke 2, 59:1-53.

B $\phi g g i l d$, O. B., 1918. Den vulkanske Aske i Moleret samt en Oversigt over Danmarks aeldre Tertiaerbjaergarter. Danm. Geol. Unders., Raekke 2, 33:1-159.

Jacqué, M., and Thouvenin, J., 1975. Lower Tertiary tuffs and volcanic activity in the North Sea. In Woodland, A. W. (Ed.), Petroleum and the Continental Shelf of North-west Europe, Volume 2. Geology: London (Applied Science Publishers), pp. 445-465.

Knox, R. W. O'B., and Morton, A. C., 1983. Stratigraphical distribution of early Palaeogene pyroclastic deposits in the North Sea Basin. Proc. Yorks. Geol. Soc., 44:355-363.

Morton, A. C., and Keene, J. B., in press. Paleogene volcaniclastic sediments of the south-west Rockall Plateau. In Roberts, D. G., Schnitker, D., et al., Init. Repts. DSDP, 81: Washington (U.S. Govt. Printing Office).

Pedersen, A. K., Engell, J., and Rфnsbo, J. G., 1975. Early Tertiary volcanism in the Skagerrak: New chemical evidence from ash-layers in the mo-clay of northern Denmark. Lithos, 8:255-268.

Date of Initial Receipt: December 3, 1982

Date of Acceptance: March 22, 1983 


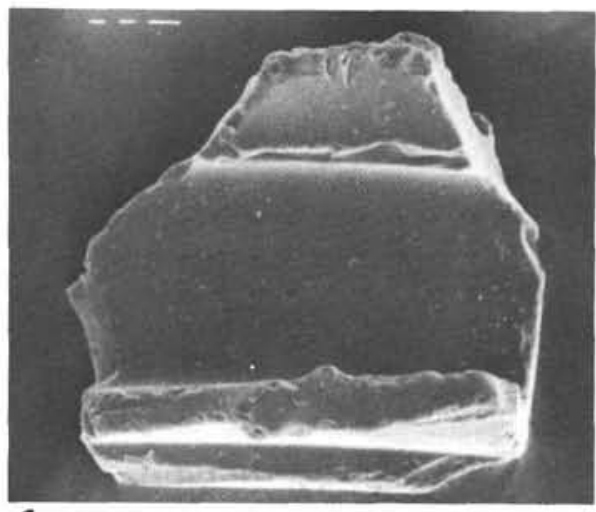

1

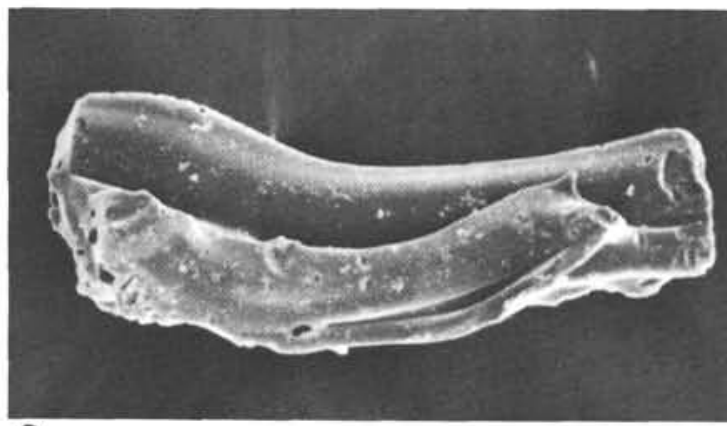

3

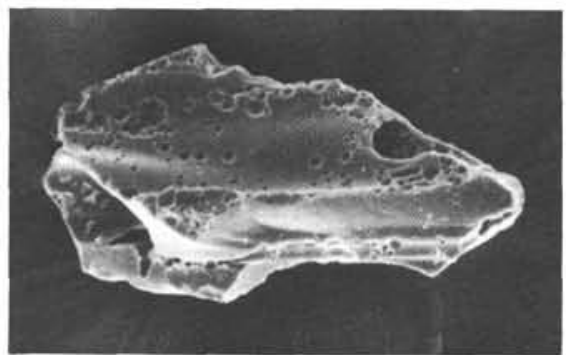

5

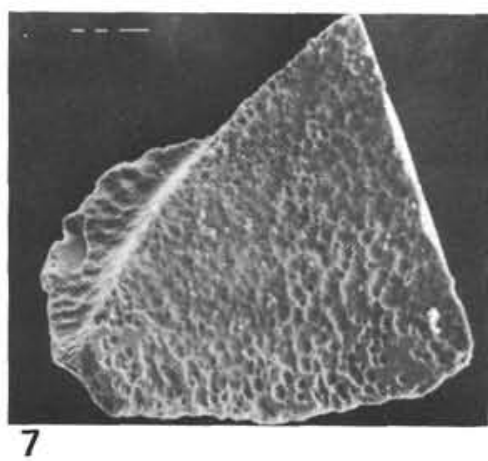

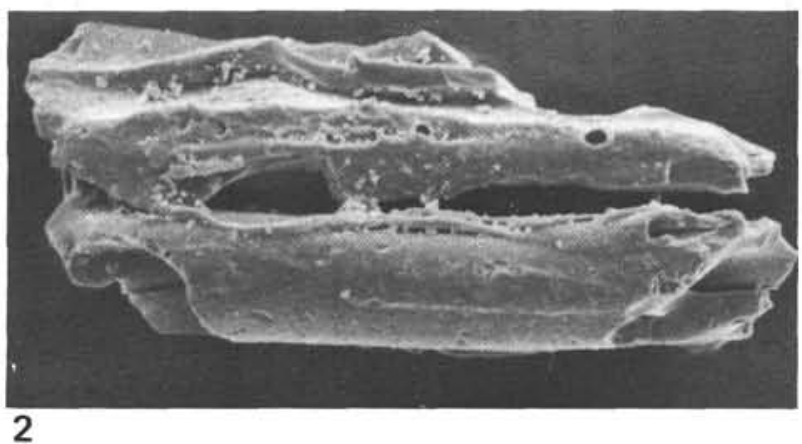

2

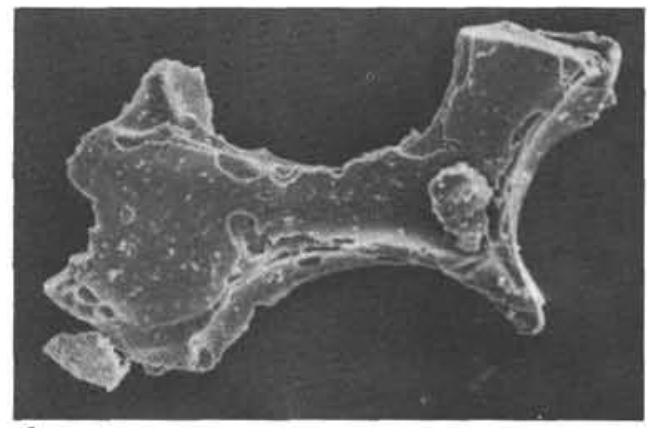

4

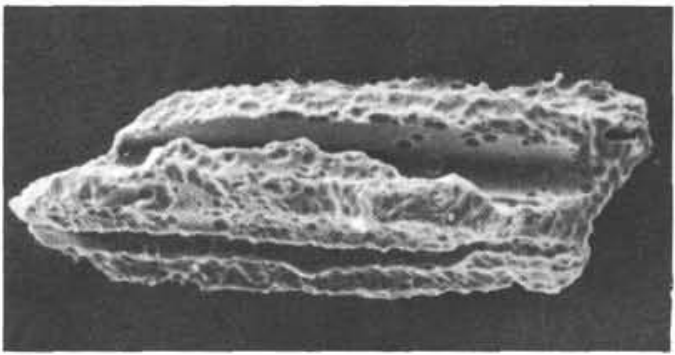

6

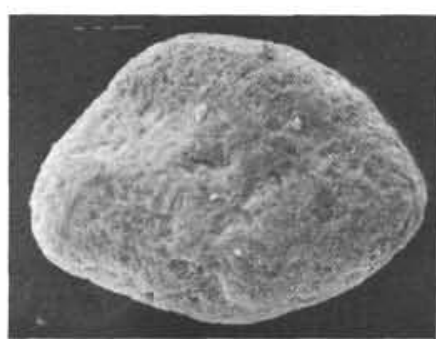

8

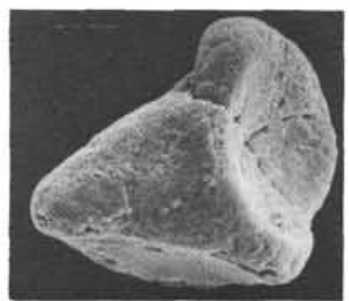

9

Plate 1. Variations in volcanic glass morphology. (All specimens magnified $\times 300$.) 1-4. Paleocene (NP9) ash, Sample $549-18-2,66 \mathrm{~cm}$, showing (1) typical ribbed surfaces and $(2,3)$ elongation, together with (4) rarer vesicle-fracture morphology. 5-7. Upper Eocene (NP18) ash, Sample 549-2-3, 129-131 cm, showing morphologies similar to those of the Paleocene ash, but with the characteristic finely vesicular texture. 8, 9. Lower Eocene (NP10) ash, Sample 550-32-1, 134-136 cm, showing equant rounded outlines, and rough surface resulting from partial argillization. 